\title{
Digitalisation in Education, Allusions and References
}

MarianNa VIVITSOU ${ }^{1}$

$\approx$ The metaphor of digitalisation in education emerged during a period when phenomena such as budget cuts and privatisation, layoffs and outsourcing of labour marked the ethos of the twenty-first century. During this time, digitalisation was constructed as an ultimate purpose and an all-encompassing matter in education. As a result, these narratives add new configurations to the metaphor of digitalisation on an ongoing basis. Such configurations attribute a mythical fullness to the concept, in the sense that digitalisation goes beyond the limits of a property that needs be developed so that society can successfully deal with contemporary challenges and advancements. In this way, digitalisation emerges as a new hegemony in education, with narratives that are more and less directly referential. Less direct references add the element of allusion to the metaphor of digitalisation, in the sense that references can be more implicit/ covert or even concealed/hidden. Moreover, as they combine with abstract terms and concepts, they make the boundaries of the technological and educational domains blurry and render education discourse vague. In order to examine the narratives of digitalisation and how they influence education discourse, this study aims to discuss and analyse relevant policy documents in relation to research and studies on the integration of digital technologies in classroom settings and the hybrid (or blended) learning environments that open up. For this purpose, the study uses thematic analysis and discourse analysis in order to trace allusions and references and discuss how emergent meanings relate to current and future needs in education generated by digitalisation itself.

Keywords: narrative, digitalisation, education, UNESCO working papers, hybrid/blended learning environments, allusion, direct/indirect reference

1 Faculty of Educational Sciences, University of Helsinki, Finland; marianna.vivitsou@helsinki.fi. 


\section{Digitalizacija v izobraževanju, namigi in reference}

MARIANNA Vivitsou

× Metafora digitalizacija v izobraževanju se je pojavila v obdobju, ko so pojavi, kot so: krčenje proračuna in privatizacija, odpuščanja in najemanje zunanje delovne sile (»outsourcing of labour«), zaznamovali etos enaindvajsetega stoletja. V tem obdobju je bila digitalizacija konstruirana kot ultimativni namen in vseobsegajoča zadeva v izobraževanju. Posledično te naracije neprestano dodajajo nove konfiguracije $\mathrm{k}$ metaforam digitalizacije. Takšne konfiguracije konceptu prispevajo mitološko polnost, in sicer v smislu, da digitalizacija presega omejitve lastnine, ki mora biti razvita, da se družba lahko uspešno spoprijema s sodobnimi izzivi in $\mathrm{z}$ napredkom. Tako se digitalizacija $\mathrm{z}$ naracijami, ki so bolj ali manj neposredno referenčne, pojavlja kot nova hegemonija v izobraževanju. Manj neposrednih referenc metafori digitalizacije dodaja element namigovanja, in sicer v smislu, da so reference lahko bolj implicitne/prikrite ali celo prikrite/skrite. Še več, ko se združujejo z abstraktnimi pojmi in $s$ koncepti, zamegljujejo meje tehnoloških in izobraževalnih domen ter proizvajajo izobraževalni diskurz, ki je nejasen. Z namenom preučevanja naracije digitalizacije in njenega vpliva na izobraževalni diskurz skuša prispevek obravnavati in analizirati dokumente relevantnih politik, ki se navezujejo na raziskovanje in študije integracije digitalnih tehnologij v učilnicah ter na hibridna (oziroma mešana) učna okolja, ki se odpirajo. Da bi lahko sledili namigovanjem in referencam ter obravnavali povezovanje vznikajočih pomenov s sodobnimi in prihodnjimi potrebami v izobraževanju, ki jih proizvaja digitalizacija, v prispevku uporabljamo tematsko in diskurzivno analizo.

Ključne besede: naracija, digitalizacija, izobraževanje, delovni dokumenti UNESCO, hibridna/mešana okolja, namigi, neposredne/ posredne reference 


\section{Introduction}

The aim of this study is to examine what new rationalities are emerging in education and society in an era when the discourse of digitalisation in education is becoming increasingly prominent and prevalent in Finland. The metaphor of digitalisation emerged during a period when phenomena such as public education budget cuts and privatisation, higher education layoffs and outsourcing of labour marked the neoliberal ethos of the twenty-first century. During the period 2015-2018, digitalisation was constructed as an ultimate purpose and, as such, an all-inclusive matter. Narratives that convey the allinclusive character of digitalisation include government documents and other policy documents, and constitute the first wave of digitalisation.

In early 2015, the newly elected government of Finland published a long-term strategic government programme that included a section dedicated to education (Finnish Government, 2015). The theme of digitalisation of education is explicit in the programme, and objectives are set to meet the need to modernise learning environments and new pedagogical approaches utilising digitalisation. Modernisation includes the government funding new learning environments to update school information and communication technology (ICT) infrastructure, teacher education and inservice training to encourage the innovative use of ICT and teaching (Haukijärvi, 2016; Saari \& Säntti, 2018). As Saari and Säntti (2018) put it, education discourse in Finland adopts the rhetoric of the information society. This stresses the possibility of bringing the education system up to date with the rest of society through the use of ICT in order to combat economic depression and the low level of productivity.

This narrative is mainly grounded in economic factors. Another relevant narrative stresses the need to move away from outdated pedagogies and learning environments in Finnish schools. As Saari and Säntti (2018) argue, while the former is constructed around a widely recognised truth, the latter might be contested. The argumentative strategy, for instance, of building a claim for the benefits of digitalisation on scientific results is weak. In addition, pedagogy-related narratives seem to calibrate themselves on securing economic competitiveness and safeguarding consensus on the necessity to update school pedagogy. However, evidence of the actual need for technology-based pedagogies seems to be lacking (Saari \& Säntti, 2018, p. 448). Saari and Säntti (2018) do not elaborate further on whether consensus has been achieved or not; however, this first wave of digitalisation narratives did indeed raise the issue of general agreement.

The first wave unfolded in the period from 2015 to 2018 and included OECD and government documents, as well as general education discourse that 
extended to the end of the previous government's term. The beginning of the new/second digitalisation wave was marked by the fact that the April 2019 elections resulted in a new government, and that UNESCO published a new working paper in the same year. Other sources that are markers of the transition include institutional strategic plans ${ }^{2}$ that aim to establish the principles for the future, and thus to play a part in the new governmental policy.

Following the strategy for digitalisation, higher education institutions (HEIs) change the ways that university-based websites and new social media distribute their virtual space. Furthermore, media practices change and become more explicit with regard to future plans for the transformation of education. This means that strategic planning including higher education and the school becomes public on the Internet. In this process, the second wave of digitalisation arises at the intersection of political and rhetorical changes. In addition to expressions directly linked with digitalisation (e.g., digital pedagogy, tools, skills, etc.), rhetorical changes include other related terms (e.g., artificial intelligence and intelligent tools).

In this way, the link between digitalisation and teacher education brought forward by Saari and Säntti's study (2018) and evident in the first wave of digitalisation remains, as does the main argument that, if the future should be digitalised, teachers should be able to make this possible. In an effort to clarify the complicated situation, European and worldwide organisations issue reports aimed at encouraging education policies that address the issue of digitalisation. Narratives of digitalisation, then, tie in with discussions concerning the present and future of teacher education. As a result, the latter intersect with European and international documents (e.g., the UNESCO working papers on education policy, (UNESCO, 2019)) and influence one another in terms of, for example, what needs are established and which terms and concepts relate to those needs.

On the other hand, we cannot ignore the fact that, as Saari and Säntti (2018) argue, official narratives (e.g., OECD, 2015a,b) neglect the historical, ideological and social structure of schools. In this way, the possibility for tension to emerge increases due to overwhelming, yet abstract, promises for education reform and the realities and challenges in schools. The fact that an all-encompassing configuration attributes a mythical fullness to digitalisation makes such tension highly possible.

To explain the mythical dimension, I draw from Laclau's (2005) analysis of hegemony and the work of Holma and Kontinen (2015) in which the

2 For example, see Mission for the Government, University of Helsinki, 2018, https://www.helsinki. fi/en/university/mission-for-the-government-2019-2023-transform-higher-education-andscience-into-a-winning-asset-for-finland. 
Gramscian perspective is discussed. Laclau (2005) links the mythical dimension of a property with the property's own limits. The Laclaudian argument is that, at some point in history, a property is attributed more meaning than it really possesses. In this sense, the property goes beyond its own limits and, as a result, acquires a mythical dimension. In our case, a mythical dimension means that digitalisation, although only a partial object in the process of social change, is viewed as the property that needs be developed so that society can successfully deal with contemporary challenges and advancements. This results in radical investment in digitalisation and technology, leading to digitalisation becoming a new hegemonic force in education. Both Laclau (e.g., 2005) and Gramsci (Entwistle, 1979; Holma \& Kontinen, 2015) posit that hegemonic forces produce new moral, cultural and symbolic orders. Consequently, new boundaries are constructed. Within this framework, the question of consensus remains open. Consensus etymologically originates from the Latin con (= together) -sentire (= agree) and signifies general agreement over an issue. If, for example, there is agreement among social actors, including teachers, parents and policymakers, that digital transformation is needed in education, then digital pedagogies are introduced in education institutions and pedagogical practice.

As consensus requires the agreement of the majority, it is not always possible to trace whether it exists or not. It is, however, possible to trace whether there is no significant objection to a decision, policy or practice. This means that if there is no significant objection there is consent, or that permission is granted for a decision to take effect. Consent can be implied, informed or unanimous. For democratic institutions to work, consent is required, coherence of different voices needs to be built, and shared solutions must be sought in order to, in the end, safeguard democracy itself (Holma \& Kontinen, 2015).

In the case of digitalisation in education, as mentioned earlier, it is not possible to know whether there is overall agreement about the necessity for digital pedagogy. What we do know, and what our research experience is telling us, is that a number of teachers have consented to integrate technologies into their pedagogical and teaching methods. Nonetheless, the dissociative rhetoric of official documents, as analysed by Saari and Säntti (2018), has brought forward a possible boundary between those in favour and those who resist the "new order". This means that both consensus and consent are at risk, especially when techniques such as praise-blame are used. As the issue cannot be resolved at this point, it is possible that the second wave of digitalisation will deepen the rift if narratives work against social consent for digitally enhanced pedagogies. For consent to exist, building coherence of different voices is needed. In this process, building alliances is essential (Holma \& Kontinen, 2015). 
Alliances establish the ground for coherent voices to take shape (Entwistle, 1979; Holma \& Kontinen, 2015), thus influencing the overall discourse. Leaders in education, teachers and educational researchers are examples of actors whose voices are critical in the process of decision making and policymaking. Although there are power relations influencing how these roles are played out in the political reality, it is not the purpose of the present study to discuss these hierarchies. Moreover, the study takes it for granted that these roles form categories of specialists who are not necessarily elites. In addition, their perspectives should be considered in educational policymaking. These specialists' voices intertwine and interrelate and are distinct from the articulations of policy documents. Coherence can arise when practitioner/specialists' voices and policies resonate each other and one another. In other words, the voices of the actors involved should echo one another and be internally coherent. To this end, they need to be part of the overall discourse.

Policies are normally based on research results and accounts of good practices, and, much like in the case of metaphors and allusion (Irwin, 2001), the relation is unidirectional. For instance, education policies issued in 2019 reflect practices applied prior to that time, while the opposite cannot occur. This means that policy documents allude to other policy documents as well as to other narratives that precede them in time. Our task here is to determine what kind of allusions these are.

The UNESCO papers target education policymakers and aim to anticipate the extent to which digitalisation and artificial intelligence (AI) affect the education sector. As a matter of fact, the 2019 paper shifts the discourse from "digital" to "artificial intelligence", which is a marker of the transition to the second wave of digitalisation. In the discussion, the working paper explores how governments and education institutions rethink and rework education programmes and the challenges and policy implications that should be the focus in global and local conversations. In order to trace how policies and practices resonate one another, and the degree to which their relation is directly or indirectly referential, the study will examine metaphors and allusions of digitalisation.

Considering these, the study aims to examine second wave digitalisation narratives in EU policy documents in order to understand how these relate to practices in the domains of technology and education. To this end, the study will offer a critical discussion of the UNESCO working papers of 2017 and 2019 in relation to research studies on the integration of digital technologies into schools during the period 2012-2016.

The selection of documents was based on the fact that UNESCO papers influence education policy and practice at different levels, ranging from the 
local to the international. Therefore, by discussing and analysing the agency's policy documents in relation to research findings, this paper aims to contribute to the overall discourse of digitalisation in education in Finland and Europe, as well as internationally.

\section{Metaphors, digitalisation and digital pedagogy}

According to metaphor theorists (e.g., Lakoff, 1993; Lakoff \& Johnson, 1980; Ricoeur, 1978; Steen, 2011), a metaphor occurs when we talk about something by means of something else, and therefore a stretch or twist is required for sense making. This metaphorical twist involves a movement to a target domain from a source domain. In our case, digitalisation in education is a metaphorical phrase that requires a stretch of thinking from the technological to the educational domain in order to better understand what technology-enhanced practices involve. Considering first wave narratives, digitalisation is a twenty-first century metaphor that signals a strategic approach to the thorough transformation of the learning space environment, one that requires pedagogical adjustments with the collaboration of experts from various domains (Haukijärvi, 2016).

A metaphor does not necessarily only mark direct references to a target domain. In the case of digitalisation, for instance, the need to make changes in pedagogical methods is a direct reference within the totality of education discourse. As a result, the term digital pedagogy emerges. What constitutes digital pedagogy, however, remains obscure until it is defined in terms of what conditions the digital dimension generates and what new teaching/learning environments arise. In this sense, the reference to digital pedagogy is, rather than explicit, less direct and more covert. Therefore, this kind of reference to digital pedagogy is indirectly referential, and thus allusive in an implicit way (Irwin, 2001).

For further elaboration, I will use the FINNABLE2020 project as an example of direct reference drawing from the field of research and practice. The FINNABLE2020 project is an example of direct reference in the sense that its rationale explicitly states the purpose of digitalisation in education. It is an umbrella project that covers a range of areas, the Boundless Classroom being one of them. The Boundless Classroom encapsulates the intention to use multiple technologies systematically and create a unified and coordinated learningfor-engagement with fun experience for primary and secondary students by combining and dispersing elements of a story across multiple web-based, digital channels and connected classrooms. For this purpose, digital storytelling was developed as a pedagogical/teaching method based on a learner-centred approach aimed at enabling learning through the use of digital devices and 
language for the production of stories in a video format. The overall aim was to give students a chance to tell their own stories about the topic under discussion, to highlight participatory practices, to increase engagement in the topic, to sustain collaborative efforts and to encourage shared learning and creativity. The conceptual basis of the implementation was grounded in the relevant literature (e.g., Hull et al., 2009, Lambert, 2013; McGee, 2015; Niemi et al., 2014; Woodhouse, 2008).

Based on the above, the material I draw on here includes research and studies performed by the research teams of CICERO Learning, the research unit at the University of Helsinki, and other relevant work. This paper, then, is to some degree an attempt to summarise our studies and projects (Niemi et al., 2014; Niemi \& Multisilta, 2016; Vivitsou, 2016, 2018, 2019a,b) with a focus on the integration of digital technologies in schools.

Research studies themselves constitute narratives that synthesise the overall education discourse on digitalisation. As the narratives of the study will be discussed within a storytelling framework with a focus on integration, not only the main storyline dimensions of technology and pedagogical practice will be considered. Moreover, the settings where the events of the narrative unfold will be part of the discussion. In the case of technology-enhanced pedagogies, settings include the environments for teaching and learning that emerge through the integration of technology in pedagogical practice.

\section{Technology integration in pedagogical practice}

The Boundless Classroom/Digital Storytelling project attracted the attention and participation of teachers, students and schools across countries and continents. It involved parent/guardian permission and included introductory sessions at which researchers communicated the project aims to the school community. In this sense, it would be safe to claim that the integration of digital technologies in the school was realised on the grounds of the informed consent of the parties involved.

For research purposes, the digital storytelling-related research and studies involved surveys, field notes, observations and interview data arising while the international projects were organised and coordinated by the University of Helsinki during the period 2012-14. At that time, students from Finland, Greece and California, and later China (2015-16), were involved in making and sharing digital stories with peers across classrooms and countries using a webbased environment. From the start, therefore, there was an emphasis on hybrid/ blended learning environments. 
Hybrid or blended learning environments combine formal and informal settings and can include virtual classrooms, real-life classrooms, field trips and so on (e.g., Niemi et al., 2014; Vivitsou et al., 2017). As a result, in this kind of learning, not only context collapses in the hybrid situations, but time collapses, as well. In their study, Marwick and Boyd (2014) argue that context collapse occurs when real-life and virtual worlds are in ongoing interaction. Consequently, real-life, face-to-face communication purposes intertwine and become inseparable from the connected interactions. In this sense, the two contexts collapse within each other. In our research experience, evidence of this phenomenon is provided by the fact that schoolwork extends to after-school hours and involves multiple actors (i.e., students, parents, teachers, software developers, and so on). Consequently, both context and time collapse.

Such a complex situation requires a pluralist orientation and involves blending methods in order to cover, for example, the need for the adaptation of previous course design and existing tools (Dziuban et al., 2018) to accommodate digital-related objectives, to establish a participatory culture (Jenkins et al., 2016), to produce multimodal texts, and to address audiences by developing topic-based argumentation in storytelling. In connected classrooms, pluralism also involves consideration of using multiple languages for communication, awareness of peers' background contexts, histories and perspectives, and deep engagement (Niemi et al., 2014; Niemi \& Multisilta, 2016) in order for student initiative to emerge (Vivitsou, 2016, 2018, 2019a,b).

\section{Hybrid/blended learning environments for shared solutions}

Considering the above, it is evident that hybrid learning situations very much depend on teachers' recursive practices taking action in both virtual and real-life classroom environments. This means that teachers construct professional knowledge in-action and at multiple levels, while observing students performing tasks and modifying decisions in situ. Recursive practices match the current need for flexible and hybridised teaching to guide and support students through the complexities of the digital era, as long as technological design satisfies such needs. In their studies, Niemi et al. (2014) and Niemi and Multisilta (2016) found that virtual spaces can encourage knowledge construction and information seeking, while the combination of formal and informal elements allows student initiative to develop with a focus on the subject matter (Vivitsou et al., 2016; Vivitsou et al., 2017). Overall, quantitative and qualitative analyses of the studies converge, in that multimodalities require literacies and competences that relate to the digital element (e.g., creating, shooting, remixing 
stories), while collaboration toward shared solutions is a unifying principle and work in groups in both virtual and natural/real-life contexts is common ground. The ultimate purpose of hybrid/blended learning environments is, therefore, to become spaces where different voices speak in a coherent manner in order to work jointly for shared solutions. In the spirit of pluralism, an overall reconceptualisation of teaching is needed, one that considers fluidity over predefined scripts and in-action professional development.

Using web-based platforms for pedagogical purposes opens up a whole array of possibilities for activities and collaborative work to both structure and problematise the process and support student work (Vivitsou et al., 2017). This type of support is determined when teachers plan classroom work and design the course of action. In this sense, a new pedagogical genre (Vivitsou, 2016) emerges, one that encompasses the ways of acting and the purposes of those who act in order to generate cross-cutting text types, ranging from descriptive to expository to narrative to dialogic and reflective. Teachers' consent to use digital means attests to these insights.

The official rhetoric (e.g., Finnish National Board of Education, 2014; OECD, 2015a,b), however, separates the high level of teacher expertise and ICT use from each other without designating the particular areas in which teacher expertise fails digitalisation. Actually, it might be the other way around. This makes first-wave narratives allusive and implicit, very often hiding meanings.

Allusion is a reference that is indirect, in the sense that it requires more associations than mere substitution of a referent, it often draws on information that is not readily available, it is typically but not necessarily brief, and it may or may not be literary in nature (Irwin, 2001). Indirect reference is necessary but does not constitute a sufficient condition for allusion. For this reason, authorial intent and the possibility of detection in principle are required. Irwin (2001) contends that authorial intent, although difficult to prove, is an epistemological and hermeneutical issue, and, as such, needs thorough investigation. This can occur through the discussion and analysis of in-text associations with other texts and narratives.

Considering these, the present study, rather than seeking intentions, aims to trace allusions and references in policy documents through associations, in order to discuss how they influence the domains of technology and education. To do so, the study will seek to respond to the following research questions:

1. How do themes from the domains of technology and education relate in the first and second wave narratives of digitalisation found in policy documents? 
2. What overt and covert references to hybrid/blended learning environments and collaboration emerge?

\section{Methods}

In order to discuss and analyse types of allusion and reference, the study will use qualitative methods and a critical discourse analytical framework. To achieve this, changes in the first and second waves of digitalisation will be examined, with a focus on how relevant terms are used. Following this, direct references (i.e., out in the open, overt) and indirect references (i.e., implied, covert) will be discussed in relation to research-based narratives with a focus on learning environments and collaboration. To this end, thematic analysis and discourse analysis will be used to discuss the UNESCO 2017 and 2019 policy documents in relation to earlier research and studies on the integration of digital technologies in the classroom.

For the initial analysis of the study, a keyword search was performed throughout the 2019 document to trace sections containing occurrences of phrases from the domain of technology and education. From the domain of technology, the lexical item "digital" and variations of "artificial intelligence" (i.e., in lower case, upper case and in the form of the initials AI) were used. From the domain of education, the items "teacher" and "teaching" were used. The results were compared with relevant searches in the 2017 UNESCO working paper. In this way, both first and second wave narratives of digitalisation were included in the database. A thematic analysis then followed, in order to identify key categories (Saldana, 2009) in the 2019 paper. Finally, a post-foundational discourse framework of analysis (Marttila, 2015) was applied to examine these types of text in relation to developments in both the technological and the educational domain.

\section{Findings}

As mentioned above, the 2019 paper shifts the discourse from "digital" to "artificial intelligence" and marks the transition to the second wave of digitalisation. In this transition process, keyword search findings indicate that the appearance of the "digital" element is still quite marked, while links are drawn to build the AI narrative in education. As discussed below, frequencies of the use of key terms play a role in this shift in discourse. 


\section{Terms and frequency of use}

As shown in Table 1 below, there is more frequent use of the adjectivenoun phrase "artificial intelligence" and less frequent appearance of "teacher" and "teaching" in the 2017 and 2019 working papers.

Table 1

Use of Terms in the Domains of Technology and Education.

\begin{tabular}{lccllcc}
\hline & \multicolumn{2}{c}{ Technology } & & & \multicolumn{2}{c}{ Education } \\
\cline { 2 - 3 } \cline { 5 - 6 } & 2017 & 2019 & & & 2017 & 2019 \\
\hline Digital & 638 & 96 & Teacher & & 197 & 84 \\
Al & 5 & 441 & Teaching & & 37 & 16 \\
\hline
\end{tabular}

Note. Adapted from UNESCO reports, 2017, 2019.

More particularly, initial analysis shows an increased occurrence of various forms of artificial intelligence in the 2019 document. In contrast, occurrences of "digital" decrease compared to the 2017 document. For instance, "digital" appears in 638 adjective-noun phrases in 2017, but in only 96 in 2019. On the other hand, the term artificial intelligence appears in a total of 441 uses in 2019. In addition, the items teacher and teaching appear in 84 and 16 mentions, respectively, in 2019, but 197 and 37, respectively, in 2017.

Following this, a later stage of the analysis focuses on the 2019 paper and aims to identify which sections make use of the digital item. The findings show that, of the three sections of the document, Section II mainly uses phrases such as digital technologies, digital skills, digital competence/competencies and digital literacy. While these appear in subsections discussing preparing learners and the need for a new curriculum, the occurrences of digital are scarce in subsections about post-basic education and higher education. In contrast, the frequency of use of artificial intelligence and its variations increases throughout the 2019 working paper.

\section{Main themes}

Thematic analysis in the sections more relevant to the domain of education reveals two major themes in the 2019 paper: preparing learners and preparing teachers. 


\section{Preparing learners for future demands}

The thematic analysis draws from Sections II and III of the 2019 document. More particularly, Section II, entitled "Preparing learners to thrive in the future with AI", presents examples from different contexts, while its subsection on the new curriculum for a digital and AI-powered world elaborates on the importance of advancing digital competency frameworks for teachers and students. This part points out the importance of developing new skills to create and decode digital technologies, and illustrates curricular reform efforts in many countries. The latter reveal the need for skills that would allow learners to identify and solve problems using computing techniques, methods and technologies. The word digital is used in adjective-noun phrases to modify words like technologies, skills and competencies. These combinations lead to the articulation of the main objective, which is to develop learner abilities to analyse, use and decode AI, as powerful technology whose scope, limitations, potential and challenges need to be understood.

The following subsection concerns digital competencies frameworks, presenting examples of frameworks and definitions of digital literacy and competencies. One of the example frameworks underlines the need for teachers to both manage digital technologies and teach them to students, in order to help students to be capable of collaborating, solving problems and being creative in the use of digital technologies.

Computational Thinking (CT) is the title of the last part of the section containing the frequent use of mainly digital +noun phrases. This subsection points out the interdisciplinary nature of $\mathrm{CT}$, in the sense that it finds applications in disciplines other than computer science. According to the document, the presence of AI in the workplace is increasing, which makes $\mathrm{CT}$ a critical competency if learners are to cope with changing labour market demands. Examples of the level of CT integration in curricula follow. In these examples, countries are clustered based on the universal recognition across the EU of the importance of integrating CT. The main categories include countries that have commenced a curriculum review and redevelopment, those that are planning to introduce such a review, and those that have a longstanding tradition of computer science education, particularly in secondary school. The subsection that follows concerns higher education and contains no use of the word digital, while the appearance of AI variations become more frequent than in the preceding sections.

\section{Challenges in preparing teachers}

Section III concerns challenges and policy implications, explaining that these should be part of global and local conversations on the possibilities and 
risks of introducing $\mathrm{AI}$ in education. One challenge is to prepare teachers for AI-powered education. This is a two-way path: on the one hand, teachers must learn new digital skills to use AI in a pedagogical and meaningful way, while, on the other, AI developers must learn how teachers work and create sustainable solutions in real-life environments

The section discussing how to prepare teachers for AI-powered education and preparing AI to understand education points out that the effectiveness of learning analytics systems lies in their usefulness and relevance to both learners and educators. The claim is made here that teachers should be given autonomy to manage classrooms and schools, as it is teachers who are most familiar with learners' needs. The report concludes that teachers will remain at the frontline of education, adding that it is misinformed to claim that AI can replace teachers. In this respect, teacher training is a critical aspect of teacher empowerment to use education data to improve pedagogy. Training programmes should account for new competencies and aim for a clear understanding and a critical perspective on technologies, development of research and data analytical skills to eventually enable teachers to take advantage of AI.

\section{Overt and covert references}

Following the thematic analysis, Sections II and III and their subsections were further analysed in order to trace overt and covert references in the policy document to the educational domains related to hybrid learning environments and collaboration. Table 2 below shows part of the results of this analysis.

Table 2

Overt and Covert References in Technology and Education/Pedagogy Domains

\begin{tabular}{|c|c|c|c|c|}
\hline & Technology & Reference & Education/pedagogy & Reference \\
\hline $\begin{array}{l}\text { Hybrid learning } \\
\text { environments }\end{array}$ & $\begin{array}{l}\text { digital devices } \\
\text { digital technologies }\end{array}$ & Overt & $\begin{array}{l}\text { digital era } \\
\text { digital content } \\
\text { digital identity } \\
\text { digital society }\end{array}$ & Covert \\
\hline Collaboration & $\begin{array}{l}\text { Academic institutions } \\
\text { with private companies; } \\
\text { between industry and } \\
\text { the education sector } \\
\text { Al developers } \\
\text { Digital Maker movement } \\
\text { Making curriculum } \\
\text { Maker framework }\end{array}$ & Overt & $\begin{array}{l}\text { Communication and collabo- } \\
\text { ration (technologies, identity) } \\
\text { (Basic) Digital literacy } \\
\text { Digital skills, } \\
\text { Digital competence and gaps } \\
\text { Digital Solutions } \\
\text { Digital Communications } \\
\text { Digital Learning }\end{array}$ & Covert \\
\hline
\end{tabular}

Note. Adapted from UNESCO report, 2019. 
As shown in Table 2 above, in the domain of technology, there are overt references to digital devices and technologies, and thus an explicit link is established with tools used in blended environments. However, the link is rather abstract and generic and, as such, very loose. The link is more explicit in the area of collaboration, although an elaboration of the conditions that should underlie the collaboration of academic institutions with the private sector would make the picture a lot clearer. Links with the domain of education are less overt in relation to both learning environments and collaboration. Again, references are rather superficial, without properly elaborating, for example, what relations exist in "digital era", "identity" and "society", and how they interact with reality.

\section{Discussion}

This is a first attempt to discuss and analyse narratives of digitalisation and draw conclusions about how these relate to developments in the domain of technology and education. More studies are therefore needed to further investigate the phenomenon and confirm or falsify the findings. For this purpose, more documents should be included in the database for analysis, drawing from the work of other social partners and actors, such as NGOs, with experience in the training and application of digital methods and literacies. The findings could then be discussed in relation to the domains of technology and education.

The present study offers insights into three main categories of examination. In terms of narrative shifts, the findings of keyword searches show that there is a movement from the digital element to the notion of artificial intelligence. More studies are therefore needed on the definitions, significations and applications of artificial intelligence, since the discussion is heading in that direction.

Although there is no direct reference (e.g., quotation) to it, the 2019 paper echoes the earlier report on "Digital skills for life and work" (UNESCO, 2017). Thus, the narrative arguing for the need to digitalise education and provide online learning opportunities continues. This provides evidence of allusion in the more recent report and, along with stylistic similarity and lexical properties, echoes the earlier one. This manifestation of allusion occurs in more and less explicit ways, and is mainly indirect and articulated through the use of phrases containing the word digital.

Consequently, the references to what online learning opportunities will be like are more covert than overt, and the meanings become, to some degree, concealed, especially in relation to hybrid/blended environments and collaboration. There are therefore gaps in the report from a methodological, 
conceptual/theoretical and practical point of view. For example, problems arising from recursive practices in hybrid situations, and solutions to tackle these problems, are not mentioned. Eventually, even if we consider the aphorism included in the report as evidence of critical discussion, the lack of associations with other parts of the text makes the allusion lose its meaning. The aphorism refers to innovations in education as full of lost promises, through failing to understand how teachers work and the culture of schools. As a result, the report suggests, AI developers need to participate in new dialogues with educators, content designers and cross-disciplinary specialists. Although the section opens up space to draw parallels with computational thinking and ground CT within the overall education discourse, this opportunity is not used.

\section{Conclusions}

The present study discusses and analyses first and second wave narratives of digitalisation in policy documents and examines how shifts in thematic choices and terminology relate to developments in the domains of technology and education. This is an important task, as government and European documents establish the ground for a consensus favourable to digitalisation in education. The importance of the task lies in the fact that the praise-blame rhetorical technique employed in first wave policy documents makes discourses of consensus and boundaries of consent blurry and divides interpretations of the teachers' role in education. On the one hand, the expertise of Finnish teachers is recognised as being high quality; on the other, their use of technology is supposed to be meagre.

Our research experience (e.g., Vivitsou 2016, 2018, 2019a,b) in the area of integrating digital technologies into classroom practices, however, has shown that teachers consent to technological integration on the basis that it expands the learning environment from conceptual, methodological and practical points of view that take into consideration the nature of digitalisation, artificial intelligence, virtual reality and other configurations of technology. Claiming that there is no need for digital pedagogy is therefore an oversimplification. However, pedagogical adjustment would require a marked reference of both parts of the adjective-noun phrase (i.e., DIGITAL PEDAGOGY, instead of DIGITAL pedagogy) to balance out the metaphor (Vivitsou, 2019b).

While the argument for pedagogical adjustments is valid, a more sophisticated approach to pedagogy is needed. Practically, this means that if teachers and the wider community are to keep renewing their consent to technology-enhanced practices, teacher education and related narratives should incorporate 
more critical and socially embedded paradigms and approaches to technology. As Holma and Kontinen (2015) point out, social consent requires building alliances to articulate coherent voices able to balance out the hegemonic force of technology and safeguard democracy. Teachers are certainly one part of this constantly evolving equation.

It becomes more and more evident nowadays, for instance, that the model of deregulation that Finland has adopted opens the door to privatisation and marketisation in education. As Hovemark et al. (2018) explain, deregulation means that state rules on the internal work of schools are delegated to lower administrative levels such as municipalities. Thus, instead of being the main provider, the state becomes the regulator of a system that becomes more and more market-oriented. The second wave of deregulation in the 2000 presents an example of the complexity of the situation. During that time, the attempt to create a school market by profiling schools, using privatisation and intensified school choice, gave rise to questions of segregation and differentiation (Hovemark et al., 2018). This put at risk the profile and the essence of Finnish education as a system that combines top quality with equality, equity and equal opportunities.

Consequently, the integration of technology in schools creates scepticism in the wider society as to who is going to be authoring the narrative of education in the years to come. Technology actors such as AI developers and companies are part of the alliance-building process. However, the limits of their role still remain uninvestigated and underdefined at this point. The UNESCO policy documents, for instance, make direct reference to AI developers and partnerships between education, industry and the private sector, but they do so in a generic and abstract manner. As the stakes are high, such partnerships should be thoroughly described, because, in the end, we will be called upon to answer hard questions regarding, inter alia, who will be making decisions: Educators? Developers? Companies? All of these? And under what conditions?

Unfortunately, the working papers do not respond to these questions at the moment; in fact, they barely pose them. From the point of view of rhetoric, it seems that the more direct references to technology-based narrative increase, the more references to pedagogy and teachers/teaching decrease and become more covert and, ultimately, concealed. However, this opens up the space for further dispute rather than consent.

According to Irwin's (2001) interpretation, we can construct allusions to purposefully elicit and include the reader's response. Moreover, Irwin adds, the goal is to please the reader/receiver of the intended message, albeit indirectly. As a matter of fact, etymology concurs with this view. Allusion has a Latin 
origin and stems from alludere (= to mock, play with). This insight offers a specific purposefulness to allusion and adds to its metaphorical gamut. On this basis, we might need to consider the possibility that allusions are by nature incomplete and the process of completing them is a productive one, which results in the most important element of the text always being missing. In our case, what is missing at the moment is a more generalised effort to put together think tanks and research to establish shared spaces for shared intelligences to confer and negotiate toward shared solutions to common problems.

\section{References}

Dovemark, M., Kosunen, S., Magnüsdóttir, B., Hansen, P., \& Rasmussen, P. (2018). Deregulation, privatisation and marketisation of Nordic comprehensive education: social changes reflected in schooling. Education Inquiry, 9(1), 122-141. doi: 10.1080/20004508.2018.1429768

Dziuban, C., Graham, C., Moskal, P., Norberg, A., \& Sicilia, N. (2018). Blended learning: The new normal and emerging technologies. International Journal of Educational Technology in Higher Education, 15(3), 1-16. Retrieved from https://doi.org/10.1186/s41239-017-0087-5

Entwistle, H. (1979). Antonio Gramsci. Conservative schooling for radical politics. London, UK: Routledge.

Finnish National Board of Education. (2014). Perusopetuksen opetussuunnitelman perusteet.

Määräykset ja ohjeet 2014 [Basic elements of the National Curriculum. Rules and regulations 2014].

Haukijärvi, I. (2016). Strategizing digitalisation in a Finnish higher education institution - Towards a thorough strategic transformation (Doctoral dissertation, Acta Universitatis Tamperensis 2181, Tampere: Tampere University Press). Retrieved from https://tampub.uta.fi/bitstream/ handle/10024/99877/978-952-03-0156-9.pdf?sequence $=3$

Holma, K., \& Kontinen, T. (2015). The rocky road of growth into contemporary citizenship: Dewey, Gramsci, and the Method of Democracy. Studier I Poedagogisk Filosofi, 4(2), 24-37.

Hull, L., Zacher, J., \& Hibbert, L. (2009). Youth, risk, and equity in a global world. Review of Research in Education, 33(1), 117-159.

Irwin, W. (2001). What Is an Allusion? The Journal of Aesthetics and Art Criticism, 59(3), 287-297. Jenkins, H., Ito, M., \& Boyd, D. (2016). Participatory culture in a networked era - A conversation on youth, learning, commerce \& politics. Cambridge, UK: Polity Press.

Korhonen, A., \& Vivitsou, M. (2019). Digital storytelling \& group work: Integrating the narrative approach in computer science education. In Innovation and Technology in Computer Science Education (pp. 140-146). ACM, New York, NY. Retrieved from https://doi.org/10.1145/3304221.3325528 Laclau, E. (2005). On populist reason. London, UK: Verso.

Lakoff, G. (1993). The contemporary theory of metaphor. In A. Ortony (Ed.), Metaphor and Thought (2nd ed., pp. 202-251). Cambridge; UK: Cambridge University Press.

Lakoff, G., \& Johnson, M. (1980). Metaphors we live by. Chicago, IL: University of Chicago Press. 
Lambert, J. (2013). Digital storytelling: Capturing lives, creating community. New York, NY: Routledge. Marttila, T. (2015). Post-foundational discourse analysis: A suggestion for a research program.

Forum: Qualitative Social Research, 16(3). Retrieved from http://www.qualitative-research.net/index. $\mathrm{php} /$ fqs/article/view/2282/3864

Marwick, A., \& Boyd, D. (2014). Networked privacy: How teenagers negotiate context in social media. New Media \& Society, 16(7), 1051-1067.

McGee, P. (2015). The instructional value of digital storytelling: Higher education, professional, and adult learning settings. New York, NY: Routledge.

Niemi, H., Harju, V., Vivitsou, M., Viitanen, K., Multisilta, J., \& Kuokkanen, A. (2014). Digital storytelling for 21st-century skills in virtual learning environments. Creative Education, 5(9), 657-671. Niemi, H., \& Multisilta, J. (2016). Digital storytelling promoting twenty-first century skills and student engagement. Technology, Pedagogy and Education, 25 (4), 451-468. doi: 10.1080/1475939X.2015.1074610

OECD. (2015a). OECD digital economy outlook 2015. Paris: OECD Publishing. Retrieved from http:// dx.doi.org/10.1787/9789264232440-en

OECD. (2015b). Students, computers and learning. Making the connection. Paris: OECD

Publishing. Retrieved from http://www.oecd-ilibrary.org/education/students-computers-and-

learning_9789264239555-en;jsessionid=5ka5a633nkgco.x-oecd-live-03

Ricoeur, P. (1978). The rule of metaphor: Multi-disciplinary studies of the creation of meaning in language (R. Czerny with K. McLaughlin \& J. Costello, Trans.) London, UK: Routledge \& Kegan Paul Ltd.

Ricoeur, P. (1992). Oneself as Another. Chicago, IL: University of Chicago Press.

Saari, A., \& Säntti, J. (2018). The rhetoric of the 'digital leap' in Finnish educational policy documents. European Educational Research Journal, 17(3), 442-457.

Saldana, J. (2009). The coding manual for qualitative researchers. London, UK: SAGE.

Steen, G. J. (2011). The contemporary theory of metaphor - now new and improved! Review of

Cognitive Linguistics, 9(1), 26-64. doi:10.1075/ ml.9.1.03ste

UNESCO. (2017). Working group on education: Digital skills for life and work. Broadband

Commission for Sustainable Development.

UNESCO. (2019). Artificial intelligence in education: Challenges and opportunities for sustainable development. In Working Papers on Educational Policy (07), Education 2030. Paris: United Nations Educational, Scientific and Cultural Organization.

Vivitsou, M. (2016). Social media and networks as communicative acts: vulnerabilities and possibilities for the pedagogies of the future: An empirical hermeneutical study of Finnish and Greek teachers and students' experiences (Research Report; No. 388). Helsinki: University of Helsinki.

Retrieved from https://helda.helsinki.fi/handle/10138/161007

Vivitsou, M. (2018). Values and purposes in digital pedagogies: A meta-analysis on Finnish \& Greek teachers' metaphorical thinking. In R. Sharma (Ed.), Innovative applications of online pedagogy \& course design (pp. 25-41). Hershey, PA: IGI Global. 
Vivitsou, M. (2019a). Constructing identities in online encounters - A study on Finnish \& Greek young students' digital storytelling practices. International Journal of Teacher Education and Professional Development (IJTEPD), 2(1), 12-29.

Vivitsou, M. (2019b). Digital storytelling in teaching \& research. In A. Tatnall (Ed.), Encyclopedia of education \& information technologies. Basel: Springer Nature Switzerland AG.

Vivitsou, M., Kallunki, V., Niemi, H. M., Penttilä, J. S. M., \& Harju, A. V. (2016). Student-driven knowledge creation through digital storytelling. In Niemi, H. \& Jia, J. (Eds.), New ways to teach and learn in China and Finland: Crossing boundaries with technology (pp. 35-54). Frankfurt: Peter Lang. Vivitsou, M. Niemi, H., Wei, G., Kallunki, V., \& Miao, R. (2017). Teachers' practices to support student work in digital storytelling: A study on Finnish and Chinese school teachers' experiences. International Journal of Media, technology and Lifelong Learning, 13(2). Retrieved from https:// journals.hioa.no/index.php/seminar/article/view/2306

\section{Biographical note}

Marianna Vivitsou, $\mathrm{PhD}$, is a post-doctoral researcher affiliated with CICERO Learning, Faculty of Educational Sciences, University of Helsinki. She has been doing research nationally and internationally on the use of digital technologies in schools. She has been developing digital storytelling as pedagogical and research method with an emphasis on the narrative perspective and draws from the media and communication studies and the educational sciences. In her work, In her recent work, Dr Vivitsou combines narrative and metaphor analysis and discourse-based analytical frameworks. She co-organizes, coordinates and teaches the "21stcentury Digital Storytelling: New Media, Technology and Frames of Reality” course, as part of the Helsinki Summer School since 2017. 